Shital Gandhi, Dan Farine (Eds.)

Obstetric Medicine 


\section{Hot Topics in Perinatal Medicine}

Edited by

Joachim W. Dudenhausen

Volume 6 
Shital Gandhi, Dan Farine (Eds.)

\section{Obstetric \\ Medicine}

The Subspecialty at the intersection of Internal Medicine and Obstetrics

\section{DE GRUYTER}




\section{Editors}

Dr. Shital Gandhi

Mount Sinai Hospital

600 University Ave, suite 431

Toronto, ON, Canada M5G 1X5

shital.gandhi@sinaihealth.ca

Dr. Dan Farine

Mount Sinai Hospital

700 University Ave, suite 3914

Toronto, ON, Canada M5G 1 Z5

dan.farine@sinaihealth.ca

ISBN 978-3-11-061459-6

e-ISBN (PDF) 978-3-11-061525-8

e-ISBN (EPUB) 978-3-11-061476-3

Library of Congress Control Number: 2021947016

Bibliographic information published by the Deutsche Nationalbibliothek

The Deutsche Nationalbibliothek lists this publication in the Deutsche Nationalbibliografie; detailed bibliographic data are available on the Internet at http://dnb.d-nb.de.

(C) 2022 Walter de Gruyter GmbH, Berlin/Boston

Cover image: Comstock/Getty Images

Typesetting: Integra Software Services Pvt. Ltd.

Printing and binding: CPI books $\mathrm{GmbH}$, Leck

www.degruyter.com 
I dedicate this book to my parents, Meena and Naresh, and to my partner Rohan for all their support over the years - Shital Gandhi

I dedicate this book to my daughter Tali and her partner Vinicius and to my son Jonathan and his partner Erin - Dan Farine 
